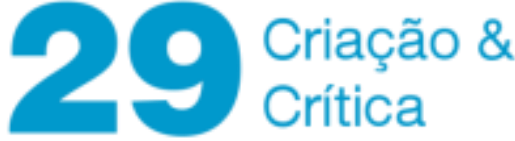

\section{“MAS AFINAL, O QUE QUEREM AS MULHERES"? O LUGAR DA MULHER NA OBRA EM SURDINA}

\author{
Edwirgens Aparecida de Almeida ${ }^{1}$
}

\begin{abstract}
Resumo: Em Surdina (1933) é o segundo romance publicado por Lúcia Miguel Pereira. Como explica Luís Bueno (2006), essa obra apresenta forte tendência documental, comum nos romances sociais da década de 30 . Assim, põe em destaque as contradições do tempo, desde a desagregação de valores, passando aos costumes, ao papel mediador do trabalho na construção das identidades, à economia e às relações internacionais. Contudo, o mais evidente diálogo com o contexto pode ser entrevisto na postura das personagens, sobretudo no temor de viver a vida por algumas mulheres. Há, na narrativa, aquelas criaturas que experimentam diversos tipos de sensações, porém a narrativa é protagonizada por Cecília. Esta tem sua existência questionada a partir do pedido de casamento. Se no discurso tradicional, o casamento constitui uma forma de controle do homem sobre a mulher, contraditoriamente, nessa narrativa, o casamento é posto, na perspectiva crítica do narrador, como a única forma encontrada pela mulher para gozar a vida. Esse convite ao carpe diem provoca em Cecília certo questionamento sobre si mesma e sobre o contexto tradicional que condiciona as práticas, sobretudo das mulheres. Portanto, a narrativa nos apresenta mecanismos de reflexões sobre o modo de vida da mulher e o lugar ocupado por ela naquela sociedade, tanto a ficcional quanto a real.
\end{abstract}

PaLAVRAS-ChaVe: Mulher; Crítica; Tradição; Década de 30; Lúcia Miguel Pereira.

\section{"BUT AFTER ALL, WHAT DO WOMEN WANT"? WOMEN'S PLACE IN THE WORK EM SURDINA}

ABSTRACT: Em Surdina (1933) is the second novel published by Lúcia Miguel Pereira. As Luís Bueno (2006) explains, this work has a strong documental tendency which is common in the social novels of the 1930s. Thus, it highlights the contradictions of time, from the breakdown of values, turning into habits, to the mediating role of work in the construction of identities, the economy and international relations. However, the most evident dialogue with the context can be seen in the characters' posture, especially in some women's fear of living life. In the narrative, there are characters that experience different types of sensations; however, the narrative is led by Cecilia whose existence has been questioned since the marriage proposal. If in the traditional discourse, marriage is the man's form of control over the woman, conversely, in this narrative, marriage is considered in a critical way as the only way for women to enjoy life. This invitation to seize the day provokes in Cecilia a certain questioning about herself and about the traditional context that conditions the practices, especially of women. Therefore, the narrative presents us with mechanisms for reflecting on the woman's way of life and the place they occupy in that society, both fictional and real.

KeYwordS: Woman; Criticism; Tradition; 1930s; Lúcia Miguel Pereira.

\footnotetext{
${ }^{1}$ Pós-doutorado em Literatura Brasileira/UFMG. Doutorado em Literatura/UNB. Doutorado em Literatura Espanhola e hispano-americana/USP. Mestrado em Literatura Brasileira/ UFMG. Professora do Departamento de Comunicação e Letras e do PPGL/Mestrado em Letras/Estudos Literários da Universidade Estadual de Montes Claros (UNIMONTES). E-mail: edwirgensletras@gmail.com.
} 


\section{Criaçäo \&}

Sabe-se que o leitor também constitui uma ferramenta essencial na atribuição do significado ao texto literário. Como um construto subjetivo que é a ficção, autor e leitor atribuem, no ato da criação e da interpretação, suas verdades a fim de delegarem sentido próprio ao escrito.

Tendo em vista os testemunhos registrados pela história, também no âmbito literário, podemos facilmente encontrar traços de realidade na ficção que vimos examinando, isto é, a narrativa Em Surdina. Ademais de registrar espaço e tempo, alguns costumes tradicionais concorrem para acentuar a maneira verossímil com que foi narrada a ambiência daquele momento. Nesse intento, é mister destacar os efeitos da rápida transformação por que passa a sociedade na qual está inserida a protagonista Cecília. De modo paradoxal, esta almeja o casamento, o trabalho e a independência financeira. No dizer de Luís Bueno "embora não possa ser classificada como uma moça de temperamento padrão, não é propriamente um espírito de exceção, de tal maneira que suas aspirações fazem parte de mundos possíveis para uma mulher da sua classe naquele momento" (BUENO, 2006, p. 318). Dessa maneira, era corrente no final do século XIX e primeiras décadas do século XX o questionamento do psicanalista Sigmund Freud (s.d.), que intitula este texto sobre quais eram as aspirações femininas.

A obra Em surdina vai colocando o leitor, pari passu, em contato com os desejos e inquietações da protagonista Cecília, o que nos remete a um olhar sobre a condição imposta à mulher nos tempos retratados pela obra. Nessa perspectiva, as atitudes e ideias de Cecília redundam numa intensa necessidade de viver a vida. Nesse sentido, convém explicar que, no decurso da estória, a protagonista trava um embate consigo mesma e com seus familiares a fim de concretizar as suas experiências. A trajetória da personagem é marcada pelos questionamentos acerca do que é e como viver. $O$ encadeamento dos fatos se dá em torno do anseio e da angústia de Cecília pelo casamento. É o próprio narrador quem nos convence da relevância deste para o curso da vida da personagem, pois explica que sua vida se dividia entre antes e depois do casamento da irmã Heloísa. Ainda nessa época, a mulher era preparada para exercer a vida conjugal. Vigiada pela família e pela sociedade, de maneira geral, o casamento burguês era uma das alternativas para mulheres da classe da protagonista de Em Surdina. Aquelas que cumprissem com honra o seu papel tinham um destino condicionado aos deveres do lar e da família, embora não raro encontrássemos aquelas que transgredissem os protocolos tradicionais, como a Heloísa. É a partir do pedido de casamento feito por Jorge Reis e do casamento da irmã Heloísa, que a personagem principal traça para si o objetivo de viver a vida e de ser feliz.

O eixo central da discussão de Em Surdina, o questionamento de Cecília sobre "quando começaria a vida, a Vida com $V$ maiúsculo? E em que consistiria?" (PEREIRA, 1933, p. 52), leva-nos a discutir as proposições que motivam a dúvida da personagem. Ela mesma responde, ao sentir a sensação de alívio ao negar o pedido de casamento de Jorge Reis, que se a pergunta houvesse sido feita semanas atrás, responderia que a vida começava no casamento. A protagonista mostra aqui uma crítica e certa insegurança decorrente das mudanças pelas quais passava a sociedade de sua época. Embora 


\section{Criaçäo \&}

almejasse o casamento, a negação do pedido deixa estabelecida a tranquilidade pela conservação de sua posição. $E$ reflete que o sossego residia em não pensar, talvez por timidez ou medo da vida, ou por uma inexplicável confiança em si e no futuro. Vê-se que a resposta é dada através de outras interrogações que refletem, como podemos ler em Bueno (2006), um romance pensado a partir da exploração de um momento de transição. Aqui, podemos pensar a personalidade da protagonista vinculada à desagregação por que passava a mulher no plano histórico. Vejamos que, se a história não foi capaz de nos mostrar os detalhes dessa desordem social, a ficção o faz com muitas minúcias.

O casamento, o trabalho e a independência financeira como uma possibilidade de aproveitar a vida e "vivê-la intensamente", como pretendia a personagem de Em Surdina, remonta-nos ao princípio horaciano do carpe diem. A expressão extraída do poema "Odes", do romano Horácio, é geralmente traduzida para "aproveite o momento, a vida". A ela atribui-se, ainda, uma justificativa para o prazer imediato, sem medo do futuro. $\mathrm{Na}$ trilha dessa significação, deslocamos para outro contexto a expressão horaciana e a utilizamos aqui para designar a preocupação com a existência que nutre o enredo do romance de Lúcia Miguel Pereira, sobretudo o anseio pelo gozo dos prazeres proporcionados pela experimentação de novas vivências como o casamento e o exercício do trabalho. Neste sentido, a autora soube apropriar-se bem do pensamento clássico para representar, ironicamente, no conturbado contexto da obra, a inquietação feminina frente às mudanças e à experimentação de outras atitudes. No caso da protagonista, o casamento contratual era algo comum e esperado para uma menina na sua posição social. Tratamos aqui do casamento como mudança, por se tratar de um novo momento na trajetória de vida de Cecília.

Revelando-se uma crítica à condição imposta à mulher ainda no século $X X$, a autora põe em debate os contrastes acerca do casamento como meio de vida para a mulher, já que este era apresentado como um fator de libertação ou aprisionamento. No âmbito das leis e dos costumes era consenso ainda que a mulher devesse se sujeitar ao marido e aos filhos. Apesar das transformações, o Código Civil de 1916 publicou um manual de economia doméstica com o sugestivo título $O$ lar feliz, "atribuindo a homens e mulheres papéis que a encíclica Rerum Novarum enfatizava em 1891: lugar de mulher era em casa, pois só aí ela salvaguardava sua honestidade sexual; só aí ela garantia a prosperidade da família, só aí ela atendia à sua natureza" (PRIORE, 2005, p. 248).

Vê-se que a perturbação com a falta de princípios éticos e valores morais na sociedade leva a gestão política e a religiosa a documentarem a divisão de tarefas e condutas de homens e mulheres. Como se vivesse nessa sociedade histórica, movida pela inquietação que desestabiliza o sentimento feminino de buscar uma forma de viver, Cecília se depara com vários agravantes que desestimulam a concretização do casamento. São algumas investidas sem sucesso como a tentativa de Jorge Reis, a sua declaração ao Tenente Sérgio Veiga, o pedido de Paulo e do Arnaldo Dias. Em todos esses momentos, Cecília tem o pensamento fixo na realização pessoal, em viver intensamente a vida. 


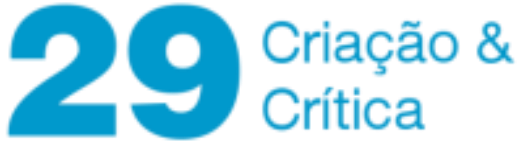

Após o alívio da desistência do casamento com Jorge Reis pelo medo do futuro, Cecília volta a se questionar sobre o que é viver a vida. Em destaque, o narrador põe entre parênteses esse questionamento que a personagem faz à norma: "(ela não podia admitir que viver fosse essa miséria: comer, dormir, trabalhar; pensarem na pândega os homens e nos vestidos as mulheres)" (PEREIRA, 1933, p. 59). O trecho reflete o inconformismo com a vida extravagante, festiva dos homens e da futilidade das mulheres. Ela mesma se revela bastante sentimental, gostar do amor dos romances e dos cinemas.

A observação dos truques da irmã Heloísa para apanhar dinheiro do marido Décio revela a 'humilhação' e a 'servidão' que o casamento escondia. Questiona também se "a vida a dois só seria possível com essa trama de pequenas vilanias, de mentiras, de subterfúgios? Duas criaturas não poderiam ser inteiramente leais - e querer-se bem?" (PEREIRA 1933, p. 92). À questão da falta de cumplicidade no casamento acresce o temor de que o casamento com Sérgio Veiga viesse a atrapalhar a intimidade intelectual cultivada com Paulo.

Para acentuar suas incertezas acerca do casamento, Cecília se depara, no ônibus, com uma colega do tempo do colégio. Yolanda era uma moça muito bonita e invejada entre as companheiras porque, aos 14 anos já era noiva. Aos vinte e poucos anos, a colega transfigurada pela obesidade, pelas ocupações exaustivas da maternidade e do casamento, adverte-a que o casamento acaba com a gente. Como não lia mais poesia como nos tempos da mocidade, Yolanda ratifica a preocupação de Cecília em prejudicar a sua intelectualidade, "case-se e verá se ainda tem vagar para essas cousas" (PEREIRA, 1933, p. 97). De modo irônico, é ressaltado o entusiasmo da colega pela 'escravidão humilde e profunda da maternidade' ou a dependência da irmã Heloísa pelo marido, o que faz Cecília revoltar-se contra essas duas servidões e se questionar se seria isso a vida feminina. Assim, ela se torna alegre por ser livre, por não ser reduzida a um 'instrumento de prazer e de procriação'. Yolanda e a irmã Heloísa são, para a protagonista de Em Surdina, como dois espelhos em que se via refletida após o casamento.

A constatação da personagem, feita através do narrador, põe em relevo os dois pilares nos quais estava alicerçada a prática feminina naqueles tempos: servir ao marido com o sexo e com a maternidade. Vê-se também que o narrador, portando um ponto de vista crítico, irônico e talvez até risível, está convicto do futuro da protagonista quando esta 'ainda' não se tornou objeto de prazer e de procriação. Parcialmente, o narrador não estava errado. O medo 'de ver correr a vida sem poder apanhá-la' e o pensamento de que 'o futuro não deixa gozar o presente' leva a personagem central a tomar a iniciativa de oficializar o noivado com Sérgio Veiga. Embora houvesse muitas controvérsias e restrições na vida conjugal feminina, Simone de Beauvoir destaca que, no século XX, ainda era comum que as mulheres desejassem o casamento como o destino traçado à existência feminina.

O destino que a sociedade propõe tradicionalmente à mulher é o casamento. Em sua maioria, ainda hoje, as mulheres são casadas, ou foram, ou se preparam para sê-lo, ou sofrem por não o ser. É em relação 


\section{Criaçäo \&}

ao casamento que se define a celibatária, sinta-se ela frustrada, revoltada ou mesmo indiferente ante essa instituição (BEAUVOIR, 1980, p.165).

Mesmo diante do quadro traçado pelas experientes Yolanda e Heloísa, Cecília se dispõe a aceitar Sérgio por marido. É ela mesma quem toma a iniciativa de conversar, porém Sérgio encenava uma brincadeira, não tomava com seriedade o namoro. Segue-se o comentário de tia Marina por via do narrador "Os homens eram assim mesmo, não davam valor às moças sérias. Se Cecília fosse uma menina espevitada, já estaria casada" (PEREIRA, 1933, p. 105).

Contradizendo esse comentário popular expresso nas páginas da ficção, a historiadora Mary del Priore (2005) ilustra que, nos primeiros 50 anos do século XX, é muito comum os homens terem receios de assumir compromissos com as mulheres ditas mais modernas, portadoras de iniciativas e experientes da vida pública. O que há, no caso de Sérgio e Cecília, parece ser uma pequena inversão desse quadro. Ele pode ser interpretado como o homem moderno, que não se envolve nos relacionamentos afetivos, priorizando as relações furtivas e descomprometidas, que o romance também põe em destaque.

De modo paradoxal, a personagem central da narrativa destaca ser bom viver os pequenos fatos do cotidiano, mas, em seguida, reconhece que "seguramente, isso não era viver"... "ela que tanto desejara viver, conhecer afinal o seu caminho, só queria poder diminuir os passos, retardar o momento do encontro com a vida" (PEREIRA, 1933, p. 132). Na trilha dessa interpretação, a protagonista, embebida da desilusão do casamento, reafirma, mais uma vez, que "encontrar-se" com a vida coincide com a prática do matrimônio.

Influenciada pelas leituras sugeridas, pela postura e pela intelectualidade de Paulo, Cecília reconhece que precisa passar a sede de liberdade e se igualar ao homem, chegando a serem companheiros para se casar, o que a instiga a ter determinadas liberdades antes de se casar. O narrador destaca, sob um olhar sarcástico, o pensamento da personagem através de parênteses "(nesse tempo já não encararia o casamento como única solução, já não precisaria casar)" (PEREIRA, 1933, p. 144). A oscilação nos anseios da personagem é condizente com as contradições do tempo. Como comenta Luís Bueno (2006), são aspirações possíveis para uma moça da classe de Cecília, mesmo que a narrativa vá, através das personagens, reafirmando a visão predominante da sociedade em questão. Acerca da recusa do casamento com Jorge Reis, o filho do abastado banqueiro, o irmão de Cecília comenta ser "dar um pontapé na felicidade". Sobre essa postura ainda conservadora da sociedade, Mary del Priore (2005) afirma que era bem mais na teoria que na prática essa possibilidade de escolha das mulheres.

O pedido de casamento de Paulo, seu guia intelectual, reacende a indignação quando ele revela considerar o casamento um emprego para as mulheres. Com o intuito de 'encher o vazio de sua existência', Paulo the oferece ser a rainha em sua casa. Novamente, o homem revela sua postura machista e patriarcal a respeito do papel exercido pela mulher na sociedade. Mesmo sendo um sujeito instruído, moderno e 


\section{Criaçäo \&}

intelectual, Paulo também portava os mesmos princípios seguidos pela família de Cecília. E adverte:

também ele achava que o seu lugar era dentro de casa, na servidão, na dependência. Oferecia-lhe um emprego de esposa, como o pai lhe oferecera de filha. Foram essas as suas palavras - era um emprego que tinha a lhe dar. Um emprego. Queria uma pessoa que lhe cosesse as meias e cuidasse da comida (PEREIRA, 1933, p. 147).

Até a irmã Heloísa, muito moderna e festeira, conclui que o futuro da mulher é o casamento, e esclarece: “- mulher solteira depois de certa idade é um perigo: dá para beata ou para maluca... Você precisa tratar de casar, Cecília” (PEREIRA, 1933, p. 247). Diante dessa vertente, a ficção testemunha e documenta o que historiadores têm observado acerca dos preconceitos com as solteiras, o que coloca em evidência a mudança de comportamentos femininos vistos pelos homens nas primeiras décadas do século.

Os motivos da recusa do pedido de casamento realizado por Paulo bem como os seus desdobramentos nos levam também a relacionar a tessitura da trama romanesca a outro princípio do mundo antigo. Desejando uma vida feliz e aprazível, a protagonista teme o futuro de solteirona, por isso quer o casamento. Mas, para ela, era preciso ser livre, precisava cultivar a amizade por Paulo, queria tê-lo como amigo, não como marido. $\mathrm{Na}$ relação de amizade, ela conseguiria ter liberdade e tempo para realizar os seus propósitos. Na vida conjugal, ela se tornaria uma serva dos desejos do marido e dos filhos. Neste ponto, a conduta da personagem permite uma breve aproximação com a idéia do filósofo grego Epicuro. Na filosofia do epicurismo, a busca do prazer e do sossego era necessária para alcançar uma vida feliz eliminando os temores do destino. A ideia de Epicuro baseava-se no fato de que, para ser feliz, o homem necessitava de três coisas: Liberdade, Amizade e Tempo para meditar. Cecília presentifica esses anseios e objetivos levantados pelo filósofo em outros tempos.

Se por um lado, o casamento é entendido como uma forma de viver a vida para as mulheres, por outra, é pintado como um modo de aprisionamento para os homens. Cláudio, irmão da heroína da história, vê o casamento para os homens como sendo uma loucura. Para ele, o casamento era uma necessidade para as mulheres. "Casar... aguentar uma família... Brrr... Que horror! Nenhuma mulher valia a sua liberdade; se podia tê-las, quantas quisesse, sem sacrificar cousa alguma" (PEREIRA, 1933, p. 27). A observação do coadjuvante no enredo é muito providencial para mostrar o reconhecimento masculino das restrições impostas pelo casamento. Priorizando as relações vulneráveis, furtivas, Cláudio afirma que o casamento priva a liberdade do homem.

Passados alguns meses no sítio para a recuperação da gripe espanhola, a vida no campo e a aceitação das dificuldades pelos camponeses levam a protagonista a entender que, na vida, é preciso se submeter. "O erro é não se submeter; é o que nós fazemos, é o que eu faço. Não me submeto a nada, por isso não sei viver" (PEREIRA, 


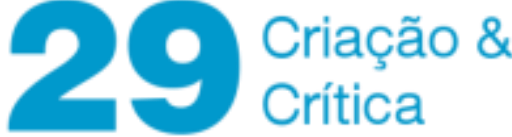

1933, p. 201). A fala pode nos denotar uma crítica a si mesma sobre a aceitação do papel social feminino. Pelo desenvolvimento da narrativa, aqui fala a voz da tradição já que Cecília, então, opta pela submissão que o casamento com Paulo representa. Chegara à conclusão que gostava mesmo dele e que 'fizera uma loucura quando o recusara, pois estava obcecada pela ideia de trabalhar, de ser independente'. "Agora, caía em si. Queria, era ser feliz, obscuramente, a seu lado. Viver dele, para ele. Tê-lo junto de si - e mais nada" (PEREIRA, 1933, p. 210). A expressão enfática "agora, caía em si", garante-nos que a tomada de atitude de Cecília fora acertada. Essa ênfase dada pelo narrador nos faz novamente pensar no teor crítico e na preocupação com a vida feminina impressa nesses romances. Assim também é a retirada estratégica da protagonista para o campo pretextando o casamento, mas que parece ter uma função de mostrar a dureza e a passividade em que se constituía a vida no campo. Contatando outras realidades, a submissão feminina passa a ser, para ela, uma normalidade, característica de outros modos de viver.

Ciente de sua decisão, Cecília não escreve a Paulo, pois se lembrava do que dizia sua avó de que uma moça nunca devia escrever a um rapaz. Reinventando discursos, as personagens fazem pequenos recortes de algumas performances daqueles tempos. No plano histórico, Mary del Priore afirma os princípios da época encontrados na ficção quando postula que, "recato era sinônimo de distinção. Moça de elite, segundo uma paulista quatrocentona, 'não tomava iniciativa em procurar o rapaz... quem se declarava era sempre ele"' (PRIORE, 2005, p. 256). Como a história, a convenção se torna uma norma quando é proveniente do discurso de uma família tradicional. Dona Ana, avó de Cecília, vivia se gabando de que todos os namoros de suas filhas eram para casar, por isso, moças sérias não deviam procurar os homens.

Ao retornar, Paulo já está casado com outra. Essa perda lhe desperta o medo do futuro e a revolta da mocidade desperdiçada. Ocupando-se de cuidar dos filhos de Heloísa, Cecília, cada vez mais, vai assumindo uma postura materna em relação aos sobrinhos e ao pai. João, o outro irmão, posiciona-se a favor de Cecília, "- cada um precisa viver a sua vida... você deve se casar... aconselhava; no Brasil, a única saída para as mulheres é o casamento... isto é a terra das convenções" (PEREIRA, 1933, p. 289). A crítica feita pela personagem ao Brasil vai endossar que, no momento da enunciação, a sociedade ainda vive presa aos protocolos tradicionais, que orientam a vida, sobretudo das mulheres.

Segue-se novo pedido de casamento, agora por Arnaldo Dias. Cecília já se encontrava com 29 anos e acreditava ser muito triste ficar solteirona e, "aos 29 anos, uma moça não tem mais tempo de esperar" (PEREIRA, 1933, p. 377). Porém, um grande empecilho na aceitação dessa união seria o fato de que Arnaldo Dias era melhor amigo de Pedro Carneiro, assumido amante da irmã Heloísa. Exalando os princípios éticos e morais de uma família tradicional, ela "não podia ser feliz num casamento assim, cujo começo se prendesse à desonra de Heloísa". "Era como se houvesse alguma coisa de turvo, de duvidoso, neste esboço de romance. Como se a lama em que se movia o outro respingasse sobre ele. E sobre ela também" (PEREIRA, 1933, p. 377). 


\section{Criaçäo \&}

Diante das impurezas em que seria construída essa relação, Cecília opta por ficar solteirona, cuidando do pai e dos filhos da irmã. Sobre a opção, Heloísa comenta: "- Olhe menina, o casamento, na pior das hipóteses, é uma carta de alforria. Uma mulher casada, mesmo mal casada, ainda é mais feliz do que uma solteirona. Ao menos tem mais liberdade" (PEREIRA, 1933, p. 342). No dizer de Heloísa, a mulher casada mantém compromisso com o marido e com a família, enquanto a solteirona tem diante de si toda uma sociedade que a vigia. E completa: "a vida como você a está levando, é uma vida incompleta, anti-natural” (PEREIRA, 1933, p. 343). Vê-se que o discurso ficcional critica, à medida que dá voz às próprias mulheres, a propagação do discurso machista e preconceituoso que estabelece um destino muito restrito para as mulheres. Nesse dizer, não apenas o cuidado com os filhos da irmã e com o pai completaria a existência de Cecília, mas ela ficaria desprovida do exercício do sexo.

Como era próprio de muitas mulheres naqueles tempos, a trajetória de Cecília revela que ela mesma se posiciona de maneira bem paradoxal acerca do casamento. Vê nele uma possibilidade de viver intensamente a vida, mas se recusa a fazê-lo por medo ou por acreditar que essa condição, em alguns momentos, pode trazer liberdade, enquanto em outros pode ser um impasse para a sua condição de mulher. Logo, a protagonista de Em Surdina não concretiza nenhum de seus propósitos, mas assume os compromissos de dona de casa no tocante aos cuidados com os sobrinhos e com o pai, deixando de lado sua afetividade e sua sexualidade acreditando, assim, ser plenamente feliz.

A crítica à tradição ressalta, ainda, o fato de que nem a personagem, nem o narrador são capazes de entender o contato do sexo desprovido do casamento. Mary del Priore salienta que ainda nesse tempo, "'aprender a ser feliz' significava literalmente aprender a ter relações sexuais regradas e contidas" (PRIORE, 2005, p. 255), sobretudo porque essa repressão sexual entre mulheres estava relacionada com a conduta moral. Para Luís Bueno, essa intercessão entre narrador e personagem é resultante do fato de que ambos se configuram como personagens de transição. "A única diferença que há entre eles, na verdade, é que Cecília é capaz de aceitar essa sua 'elevação' em relação aos instintos sem maiores questionamentos, enquanto o narrador precisa dar a ela alguma razão - e encontra uma em Deus" (BUENO, 2006, p. 325). Bueno refere-se aqui ao fato de o narrador inserir uma citação de Rilke, extraída de Histórias de Deus, no último capítulo da narrativa, totalmente desvinculado do enredo, apenas para justificar as ações da protagonista. Essa inserção da religiosidade, no último momento do romance, aproxima novamente a ficção aos artigos de Lúcia uma vez que, na revisitação de seu acervo encontramos boa dose de menção aos dogmas católicos, sobretudo quando escreve para a revista $A$ Ordem. Contraditoriamente, aqui, o narrador parece não mais se apegar ou criticar a religião católica, mas apenas a religiosidade, pois Rilke, apesar de ter a preocupação com o espiritual em seus poemas, não se sabe católico.

Como extraímos do texto, de forma sutil, princípios religiosos e traços de filosofia grega e romana, convém destacar que não intencionamos atribuir ao texto características de outros tempos, contudo transportamos a mesma significação dos princípios do 


\section{Criaçäo \&}

epicurismo e do carpe diem para mostrar como o romance em estudo mescla tradição e modernidade. Logo, revisitando o pensamento de Luiz Costa Lima, o sentido do texto é construído a partir do criador e do receptor. Sob essa matiz, a autora deixa as pistas e, com base nessa interpretação da trama narrativa, podemos assegurar que ela produz, com intenso sentimento de verdade, a inquietação feminina diante da possibilidade de viver através do casamento, seja ele uma iniciativa de liberdade ou de aprisionamento.

\section{O trabalho: realização pessoal ou mediação da identidade}

Uma mulher só se torna mulher na medida em que trabalha seus conflitos e encontra seu lugar em uma determinada estrutura de relações sociais.

Andrea Nye

A expressão de Andrea Nye (1995) pode ser facilmente relacionada ao pensamento de Simone de Beauvoir (1980) quando esta adverte que a mulher não nasce mulher, mas se torna mulher. Esse caráter construído da identidade feminina identificado por Beauvoir é materializado, nas palavras de Nye, quando a mulher passa a conhecer e administrar seus anseios e suas inquietações conseguindo impor-se diante da sociedade em que está inserida, ocupando nela o seu espaço.

De maneira condizente com o que teorizaram Beauvoir e Nye, a personagem Cecília, do romance Em Surdina, procura conhecer-se, marcar a sua trajetória no meio em que vive para, enfim, alcançar a liberdade. Algumas de suas tentativas são frustradas. Com isso, podemos ver que as tensões sociais não puderam ser resolvidas pela ficção. Através do casamento, como vimos esclarecendo, a personagem procura estabelecer o seu papel na sociedade e garantir uma existência plena e feliz. Mesmo com a invasão de tecnologias e meios de comunicação, o uso de saltos baixos, maiôs e saias curtas no cotidiano da classe média, a emancipação feminina continuou extremamente limitada. Algumas dessas práticas eram consideradas um escândalo e, ainda nas primeiras décadas do século XX, o casamento ainda é uma das mais indicadas formas de vida para a maioria das moças, sobretudo as burguesas, comenta Priore (2005).

$\mathrm{Na}$ busca da realização pessoal, depara-se com ideias e posturas contraditórias às suas, por isso a personagem central de Em Surdina vê frustradas as suas tentativas de casamento e, influenciada por uma colega, recorre a outra possibilidade: o exercício do trabalho e a independência financeira. "Você nem calcula como é bom trabalhar; a gente se sente útil e, sobretudo independente; ganha o seu dinheirinho, não tem que dar satisfação a ninguém do que gasta" (PEREIRA, 1933, p. 134). O comentário a faz lembrar a atitude da irmã Heloísa, que guardava, pouco a pouco, o dinheiro do marido para comprar as 'coisas de mulher'. E ela estava decidida a conquistar sua liberdade, seu espaço e preencher o vazio que ela mesma sentia. "_ Falaria com o pai; ele tinha tantas relações, não the haveria de ser difícil arranjar um lugar. Ela falava francês e inglês, escrevia regularmente na máquina... talvez mesmo pudesse conseguir um ordenado de $500 \$ . . . \mathrm{Na}$ Europa, na América, todas as moças trabalhavam..." (PEREIRA, 1933, p. 134). A expressão revela a influência das transformações pelas quais passa o contexto histórico 


\section{Criacāo \&}

representado na ficção. A negação do pai é justificada por ser resultado das mudanças pelas quais passa a Europa, mas afirma que no Brasil ainda há família. A negação do pai é coerente com a justificativa histórica de que a inserção feminina no trabalho assalariado se configurava como uma forma de ajudar nas economias do lar, caso o marido não o conseguisse sozinho. Porém, essa não era a realidade de Cecília. Essa explicação põe em relevo a discussão sobre a preponderância dos princípios tradicionais além de sugerir a tendência de ordem e preservação da família tão criticada nesse legado ficcional. Porém, o desejo de Cecília revela também a necessidade de ocupação e realização que a mulher passa neste mesmo momento.

Paola Cappellin Giulani argumenta que, mesmo com algum número de mulheres inseridas no mercado de trabalho, "muitas vezes, as trabalhadoras nem são reconhecidas como parte da população economicamente ativa; sua contribuição social reduz-se ao papel de mantenedoras do equilíbrio doméstico familiar" (GIULANI, 1997, p. 641). Podese notar que, apesar do empenho feminino nas primeiras décadas para inserir-se e ser reconhecidas no mercado de trabalho, inclusive com o recebimento de justos salários, as mulheres têm a sua função reduzida a donas de casa.

O diálogo travado entre Cecília e seu pai é exemplar da conduta feminina imposta pela tradição.

\footnotetext{
- Trabalho de moça é em casa. Olhe, você quer serviço? Pois então arrume os meus livros, que andam numa desordem horrível... Ora, essa bobinha a querer trabalhar. Como se não tivesse pai para sustentá-la! Então você pensa que já estou imprestável, que não posso mais manter meus filhos? (PEREIRA, 1933, p. 136)
}

A opinião do Sr. Vieira acerca do trabalho feminino ressalta as restrições pelas quais passa a mulher ao ingressar no trabalho assalariado. Ele acredita que o homem deve ser o provedor da mulher evitando a saída desta para o espaço público e, assim, manter a ordem da vida familiar. Completa o pai que isso era caprichos de mulher e que, com alguns $100 \$$ ou $200 \$$ por mês a faria esquecer. O que ela precisava mesmo era se casar. "Essas veleidades de independência, esse gênio esquisito, isso tudo era falta de marido" (PEREIRA, 1933, p. 137). Mais uma vez, a narrativa chama a atenção para o discurso patriarcal quando destaca o casamento como única forma de vida da mulher. Sob esse ponto de vista, a mulher passa do controle e da dependência do pai para a o domínio do marido.

Segundo o relato do pai:

_ Ainda uma conseqüência da guerra. Mas as situações são diferentes. Aqui os homens não estão nas trincheiras, e as mulheres não precisam abandonar o lar para substituí-los. Substituí-los e se perderem, como acontece quase sempre. No Brasil, graças a Deus, ainda há família! (PEREIRA, 1933, p. 202). 


\section{Criaçäo \&}

$\mathrm{Na}$ fala do pai, o ponto de vista se confunde com muitos outros expostos naquele contexto. Em artigo, Márcia Cavendish Wanderley (1999) destaca que a autora mesma apresenta esse pensamento autoritário da época, quando critica que usar a mulher no serviço militar é desvirtuar o seu papel, que é de mãe, acolhedora e preservadora da ordem familiar. O exercício do trabalho é, para a autora, uma forma de se perderem as qualidades 'naturais' das mulheres, como realça também a sua criação. Embora estejamos cientes de que o trabalho remunerado, ao qual a personagem aspirava seja distinto do serviço militar, a autora se refere na crítica a quaisquer atividades femininas fora do lar, ou melhor, qualquer confrontação que as coloque em exercício diferente da ordem doméstica. Sobre essa postura da autora, em seus textos críticos, a mesma, ao longo de sua atuação no campo das letras, avança em relação a essa entrada da mulher no campo de trabalho, já no plano da ficção, o trabalho da personagem central do livro Amanhecer, por exemplo, não é suficiente para trazer a sua emancipação. Isto é, se criticamente Lúcia Miguel caminha no sentido de ver como positiva a entrada da mulher no mercado de trabalho, escrevendo textos de ficção não deparamos com essa mesma postura da autora.

Mas Cecília queria ser livre, ser dona de si, gozar a vida. E indaga a indiferença do pai pelos seus sentimentos, pela sua realização. "Ele quer que eu ande bem vestida para lhe fazer honra, pensava; faço parte de sua representação, como o automóvel e a pérola da gravata" (PEREIRA, 1933, p. 143). A mulher se sente um objeto em relação ao homem. Para o pai, Cecília era um instrumento com o qual ele revelava a sua condição e postura social. Mas, procurando um lugar social, Cecília tinha a impressão de que só seria ela mesma quando tivesse realizado alguma coisa.

Também em Paulo, Cecília encontra um empecilho para seu ingresso no mercado de trabalho. Ela pensava encontrar nele um apoio para sua nova investida. Mas ele, apesar de ser um intelectual, oferece-lhe o casamento como uma forma de trabalho. Através de Paulo, a narrativa mescla bem os distintos comportamentos da tradição e da modernidade. Mais uma vez, o ofício da mulher é definido pelo homem e pelo próprio gênero feminino. Por ser mulher, o ofício que lhe resta é o de dona de casa. Assim, interpela Paulo, "que pode você esperar de maravilhoso, de extraordinário, em ser uma empregadinha, em ganhar umas miseráveis centenas de mil réis por mês? Se é esse o seu ideal, não the dou parabéns (PEREIRA, 1933, p. 149)". Como a historiografia nos informou acerca da desaprovação do trabalho feminino pela sociedade, este é depreciado na representação pelo termo "empregadinha". A crítica aqui às dificuldades de entrada da mulher no mercado de trabalho é bastante evidente. Como ressaltamos, a justificativa para o trabalho feminino no Brasil, na primeira metade do século XX, era a de que o marido não ganhava o suficiente para manter a família. Isso valia especificamente para a classe média e significava, em certa medida, humilhação para o homem. Assim, dada a condição econômica de Cecília, a argumentação de Paulo e a do Dr. Vieira têm razão de ser. Cecília, portando uma postura paradoxal a outros pensamentos e práticas no decurso da história, por outro lado, queria que os dois vissem além das convenções, que a vissem como sujeito. Nesse sentido, ela se afasta da condição de conservadora. 


\section{Criaçäo \&}

Veja que Paulo, embora seja um rapaz com traços modernos, age com extrema conservação dos protocolos machistas ao falar do acesso feminino ao mundo do trabalho, da independência. Cecília tem em Paulo um guia intelectual, também aqui ela confia a ele o incentivo para a mudança. A indignação com a reação de Paulo não é seguida de ação da protagonista, mas de conformação no decurso do enredo. Sobre essa conduta pusilânime e inoperante que as mulheres, geralmente, manifestam diante do homem, Branca Moreira Alves e Jacqueline Pitanguy postulam: "a mulher, ainda uma escrava, permanece em silêncio... Subjugada pelo domínio masculino, ela nem sequer aspira à sua própria libertação, o homem é que deve libertá-la" (ALVES, PITANGUY, 1983, p. 39).

Do lado da ficção, Cecília vislumbra no trabalho uma possibilidade de criar a sua independência, a sua personalidade,

era o único meio de criar a sua personalidade, independente do núcleo familiar; tinha a impressão de que começaria afinal a viver, no dia em que começasse a dedilhar na máquina ofícios e cartas comerciais. As primeiras sílabas batidas numa Remington seriam a fórmula mágica, o 'abre-te sésamo' maravilhoso. Então entraria na posse de si mesma, e da existência. Escolhia os seus hábitos, as suas relações, o seu modo de vida (PEREIRA, 1933, p. 143-144)

A reflexão da personagem no excerto acima evidencia os seus objetivos, como esclarece Andrea Nye (1995) na epígrafe que inicia este estudo. Para a criatura ficcional, é preciso ocupar o seu espaço, escolher seu modo de vida e marcar a sua personalidade dentro de uma estrutura de relações sociais.

Em conversa com o irmão João sobre o futuro da sobrinha Baby, depara-se com um incentivo ao seu sonho. Diz o irmão, "o trabalho liberta a mulher moralmente, ainda mais do que materialmente. Se ela não se casar, não se resignará também a viver" (PEREIRA, 1933, p. 360). Do lado da história, encontramos também mulheres que veem no trabalho um instrumento de libertação e de liberação da mulher no meio social. Mary del Priore estudando sobre a prática do sexo fora do matrimônio pela mulher, nos tempos de antes e após a Primeira Guerra Mundial, cita Ercília Nogueira Cobra que ousava dizer: "a mulher que teve intercurso com homens antes de casada é tão honrada como o homem nas mesmas condições, uma vez que ela tenha uma profissão e viva honestamente de seu trabalho" (PRIORE, 2005, p. 258). Nota-se na advertência da escritora feminista que, mesmo que a mulher quebre o 'interdito ao sexo', a 'pedra-de-toque da tradição', utilizando as palavras de Nelly Novaes Coelho (2002), pela ótica feminina, a mulher consegue se redimir dessa transgressão através do trabalho. Nessa concepção, o trabalho passa a ser visto como um purificador, uma forma de libertação moral.

Também podemos depreender da questão que, o que está implicado aqui é que a mulher que tem um trabalho honrado e não fez sexo por dinheiro, não se prostituiu. Por esse lado, o trabalho não pode ser entendido como uma redenção de uma falta, porque a prática do sexo não é vista como falta. O que é visto como falta é a 


\section{Criação \&}

prostituição. A reação do Dr. Vieira e de Paulo acerca do ingresso de Cecília no mundo do trabalho revela também que este passa a ser visto como uma estratégia de definição da identidade pessoal, manifestada, principalmente, pela preocupação com as aparências no meio social. Diz o pai: "Que parecerá isso? Uma filha minha andando empregada! Vão dizer que sou sovina, ou que estou perdendo a clínica. Você não vê que isso me prejudica, Cecília?" (PEREIRA, 1933, p. 136). Pelo exposto, a posição ocupada na sociedade, a identidade e a postura de cada sujeito são construídas no meio social em que este está inserido. Dessa forma, o provedor da família tende a nutrir a sua hegemonia através do jogo de aparências. Cláudio apresenta a influência que as aparências exerciam sobre a família.

Vaidade ridícula, só possível mesmo no Brasil. Na América, ninguém cuidaria disso. Preconceito. Ele, Cláudio, não era formado, e, nem por isso se sentia inferior. Ao contrário. Poucos rapazes da sua idade ganhariam tanto quanto ele. Mas bem percebia que a família se vexava de ter de apresentá-lo ‘seu Cláudio'.

O pai não the perdoava não se ter formado em medicina. Bobagens. $O$ mundo moderno era dos industriais e dos comerciantes. Cláudio Vieira, comissões e consignações... (PEREIRA, 1933, p. 27).

No relato da personagem, veja-se que era comum, desde aquele tempo, a valorização e a identificação da pessoa através de sua profissão. $O$ trabalho torna-se assim um mediador na identificação da personalidade do sujeito. Também se converte em um meio de dar prestígio social à família.

Para Cláudio, o trabalho permite o gozo da vida. Observa-se o diálogo estabelecido com a irmã Cecília:

\footnotetext{
não dou para filho-família. Cavo, mas gozo... Vocês mulheres não podem entender isso. Vivem presas a uma porção de tolices, de convenções. A gente só leva desse mundo o prazer que teve. Eu trabalho muito, para me divertir muito. Mas aproveito a minha mocidade. Ter dinheiro quando estiver careca e reumático? Muito obrigado. Não serve (PEREIRA, 1933, p. 261).
}

Os princípios romano e grego aparecem mais uma vez no discurso ficcional. Cláudio procura viver intensamente porque acredita na brevidade da vida. Para ele, o trabalho garante o dinheiro para se aventurar, para se realizar pessoalmente. Nesse viés, a realização, o encontrar-se consigo mesmo, o preenchimento da existência possui conotações bem diversas para os dois irmãos. Aspecto distinto pelo gênero de cada um. O que o trabalho permitiria para Cláudio, ainda estaria restrito a Cecília, o gozo da vida através da vulnerabilidade das relações.

Noutra vertente, o pai critica ainda a escolha da profissão de escritor e jornalista do filho João, "No Brasil, os literatos morrem de fome" a partir da explicação 


\section{Criação \&}

de que pensava na escrita de artigos sobre as diretrizes da mentalidade contemporânea. Dá seguimento o pai: “-Ah! Então você quer ser jornalista? Ingenuidade. Jornalismo no Brasil é um subproduto da política. Só enriquece os venais. E você precisa trabalhar; já está com vinte e quatro anos..." (PEREIRA, 1933, p. 291). Para Dr. Vieira, a escrita do literato e do jornalista não constitui um trabalho, ademais está subordinada ao poder político. Por isso, não são atividades lucrativas nem trazem prestígio para si nem para a família.

Voltando à relevância do trabalho na vida feminina, Paulo, após o casamento, dá indícios mais claros acerca do papel exercido pelo trabalho extra doméstico na vida da mulher. Depois de questionado por Cecília sobre o abandono da profissão de professora pela esposa, explica que, desde que eles se casaram ela não ensina mais. "Antes precisava ganhar para educar a filha; ficou sozinha com a menina com dois anos, mas agora não há mais necessidade disso. Eu não compreendo as mulheres trabalhando senão quando são forçadas pelas circunstâncias... têm muito no que se ocupar em casa" (PEREIRA, 1933, p. 238). A explanação de Paulo deixa evidente que o trabalho feminino deve ser decorrente da sua necessidade. Fica marcado então o princípio tradicional de que deve ser o homem o provedor da mulher.

Se o trabalho figura como mediador na vida de homens e mulheres ficcionais, referimo-nos aqui àquele trabalho remunerado e exercido no espaço público. Veja-se que as atividades de casa caracterizadas por Paulo e Dr. Vieira como empregos para as mulheres, redundam apenas em uma 'ocupação'. Para esses homens, a mulher precisa manter o seu tempo ocupado para não 'pôr a família à perdição'. O comportamento masculino, nesse caso, ainda sugere o impedimento da ação feminina no espaço até então destinado apenas ao homem, o espaço público. $\mathrm{Na}$ visão masculina, se as ocupações da mulher alcançam os domínios do homem, esvaem-se as diferenças de poder e valor entre eles. Nessa dinâmica, o espaço social ocupado por eles passa a ser dividido com as mulheres, o que pode colocar em crise sua identidade. Isso posto, assegura Elizabeth Badinter: "na escala social, os homens se sentem ameaçados em sua identidade por essa criatura que quer agir como eles, ser como eles. Para eles é a verdadeira dissolução de sua especificidade" (BADINTER, 1993, p. 16).

$\mathrm{Na}$ trilha dessa concepção, apesar de suas aspirações, a trajetória de Cecília presentifica os rastos da tradição falocêntrica e patriarcal quando reafirma o estigma da mulher. Segundo Margareth Rago, o momento em que várias atividades exercidas na unidade doméstica, como a fabricação de pães, manteiga, doces foram transferidas para a fábrica, desvalorizaram-se os serviços relacionados ao lar.

Ao mesmo tempo, a ideologia da maternidade foi revigorada pelo discurso masculino: ser mãe, mais do que nunca, tornou-se a principal missão da mulher num mundo em que se procurava estabelecer rígidas fronteiras entre a esfera pública, definida como essencialmente masculina, e a privada, vista como lugar natural da esposa-mãe-dona de casa e de seus filhos (RAGO, 1997, p. 591). 


\section{Criacāo \&}

Dá seguimento à questão, Margareth Rago;

O trabalho feminino fora do lar passou a ser amplamente discutido, ao lado de temas relacionados à sexualidade: adultério, virgindade, casamento e prostituição. Enquanto o mundo do trabalho era representado pela metáfora do cabaré, o lar era valorizado como o ninho sagrado que abrigava a 'rainha do lar' e o 'reizinho da família' (RAGO, 1997, p. 588).

O esclarecimento da historiadora revela que, com a entrada da mulher no espaço público, este se tornou algo ameaçador para sua moralidade. Assim, aumentou a apreensão sobre a conduta daquelas mulheres, sobretudo casadas. Temos, na representação, a própria personagem que, impedida do trabalho remunerado, opta pela vida do lar, cuidando do pai e dos filhos da irmã. Para as personagens que circulam pela narrativa, encontramos distintas formas de entender a entrada da mulher no mercado de trabalho: para o pai de Cecília redunda numa ofensa, significando a decadência de um pai mantenedor da família e a perdição da conduta feminina. Nos gestos de Paulo, o trabalho é encarado como uma necessidade, e é justificado por determinadas circunstâncias. Para Cecília e para João um fator de libertação. Como estratégia, a escrita de Lúcia Miguel Pereira mostra, nas diversas abordagens do trabalho na vida feminina, a dinâmica do tempo dissolvendo o social no literário, a saber, a autora traz vestígios do tempo histórico para as páginas da ficção quando escreve um texto que, ao mesmo tempo em que critica, coloca em evidência práticas predominantes do tempo.

\section{Referências bibliográficas}

ALVES, Branca Moreira; PITANGUY, Jacqueline. O que é feminismo. 3. ed. São Paulo: Brasiliense, 1983.

BADINTER, Elisabeth. XY: sobre a identidade masculina. Rio de Janeiro: Rocco, 1993.

BEAUVOIR, Simone de. O segundo sexo: a experiência vivida. Trad. Sérgio Milliet. Rio de Janeiro: Nova Fronteira, 1980.

BUENO, Luís. Uma história do romance de 30. São Paulo: Editora da Universidade de São Paulo; Campinas: Editora da Unicamp, 2006.

COELHO, Nelly Novaes. "A literatura feminina no Brasil - das origens medievais ao século XX”. In: DUARTE, Constância; DUARTE, Eduardo de Assis; BEZERRA, Kátia. (Orgs.) Mulher e literatura: I- gênero e representação. Teoria, história e crítica. Belo Horizonte: Ed. UFMG, 2002. Coleção Mulher \& Literatura.

PRIORE, Mary del. História do amor no Brasil. São Paulo: Contexto, 2005.

FREUD, Sigmund. "A feminidade". Trad. Odilon Galloti, Isaac Izecksohn e Gladstone Parente. In: FREUD, Sigmund. Obras completas de Sigmund Freud. Rio de Janeiro: Delta, s.d. p.117-141.

GIULANI, Paola Cappellin. "Os movimentos de trabalhadoras e a sociedade brasileira". In: PRIORE, Mary del. História das mulheres no Brasil. 2 ed. São Paulo: Contexto, 1997. 


\section{9 criacio \& \&}

NYE, Andrea. Teorias feministas e as filosofias do homem. Trad. Nathanael C. Caixeiro. Rio de Janeiro: Recorde: Rosa dos tempos, 1995.

PEREIRA, Lúcia Miguel. Em surdina. Rio de Janeiro: Ariel, 1933.

RAGO, Margareth. "Trabalho feminino e sexualidade". In: DEL PRIORE, Mary. História das mulheres no Brasil. 2 ed. São Paulo: Contexto, 1997.

WANDERLEY, Márcia Cavendish. "Lúcia Miguel Pereira: do conservadorismo ao liberalismo". In: RAMALHO, Christina (Org.) Literatura e feminismo: Propostas teóricas e reflexões críticas. Rio de Janeiro: Elo Editora, 1999. p.73-84.

Recebido em: 09/04/2020 Aceito em: 08/05/2020

Referência eletrônica: ALMEIDA, Edwirgens Aparecida Ribeiro Lopes. "Mas afinal, o que querem as mulheres?" O lugar da mulher na obra Em surdina. Criação \& Crítica, n. 29, p., mai. 2021. Disponível em: <http://revistas.usp.br/criacaoecritica>. Acesso em: dd mmm. aaaa. 